\title{
Ten Years of Research in the Journal of Family and Economic Issues, and Thoughts on Future Directions
}

\author{
Elizabeth M. Dolan ${ }^{1}$ (D)
}

Accepted: 30 October 2020 / Published online: 13 November 2020

(c) Springer Science+Business Media, LLC, part of Springer Nature 2020

We always begin our research reports with a review of the literature to orient ourselves, and our readers, to what prior research has revealed about our topics. This Special Issue is a review of the research published in the Journal of Family and Economic Issues (JFEI) over the last 10 years. This past decade has been an important one for JFEI as it has experienced phenomenal growth - in both numbers of submissions and in prestige. While the number of submissions had been growing steadily throughout the decade, acceptance into the Social Sciences Citation Index (SSCI) to start receiving an impact factor fueled the number of submissions, in addition to the reputation of the journal. Therefore, it seemed fitting for us to review what we have learned from the last 10-years of JFEI publications and make suggestions regarding where researchers should focus their efforts in the future.

Discussions between Joyce Serido and Elizabeth Dolan revolved around how to publish what would inevitably be something too large for a single issue of JFEI. With input from JFEI's Springer liaison, it was determined that a virtual journal issue would be the appropriate platform. Since one of the primary goals was to move research forward with suggestions for future research, we decided to also publish all the future directions sections in the December 2020 issue of JFEI.

The authors were given very few instructions on how to proceed with their task. They were sent the list of papers to review, told to focus on the JFEI papers, limit outside references, and to end their reviews with their thoughts on future directions (limited to about 2 pages). The reader will find that authors approached their themes in different ways which makes for interesting reading. Some authors

This is one of several papers published together in Journal of Family and Economic Issues on the "Special Issue on Virtual Decade in Review".

\footnotetext{
Elizabeth M. Dolan

1 Firefly Circle, Somersworth, NH 03878, USA
}

warmed to the topic of future directions with many more than 2 pages. These authors were given the option of keeping what they had written for this virtual journal and writing a separate closer-to-2-pages version for publication, or simply cutting their future directions down to about 2 pages. Several authors (e.g., Dew, Bartholomae and Fox, Wilmarth) chose to write a separate, shorter version for publication. Therefore, what you read in JFEI's December 2020 issue will be different (i.e., shorter) than what you will read here.

In 2008, Jeffrey Dew published an overview of JFEI publications from 1988 to 2007 (a total of 420 papers). He identified 15 themes, or categories, of papers. In descending order of number of papers on the topic, the categories Dew (2008) identified were: family resource management (52 papers), division of labor, gender roles, women's labor force participation (40 papers), employment and work-family issues (39 papers), economic issues and family relationships (38 papers), family policy (33 papers), family-owned businesses, home-based business (29 papers), time use (28 papers), poverty, public assistance (27 papers), caregiving (23 papers), consumer attitudes and behavior (23 papers), health and health services (17 papers), intergenerational or interhousehold exchanges (15 papers), rural families (15 papers), contraception, reproduction, and sexual behavior (14 papers), and housing (13 papers). Dew did not, however, summarize the findings nor make suggestions for future research, which were the foci of this endeavor.

Like Dew, Dolan also read through all the paper abstracts, and sometimes more, to put the papers published in Volumes 31-40 (2010-2019) into some sort of order. Over this decade, 441 papers were published in JFEI, twice the number published between 1988 and 2007. In the end, 17 themes, or categories, of papers were identified. As one might suspect with a multi-disciplinary journal such as JFEI, some manuscripts were difficult to categorize. The themes developed are not mutually exclusive. For example, financial issues of college students became its own theme, although much 
of what appears in that theme could be reallocated to the themes of financial behavior and/or financial socialization and literacy; research with Asian family samples appears in several categories when the focus was more on the type of research than on where the sample was collected. Any errors regarding how any of the manuscripts were classified belong to Dolan alone, as the authors were sent the list of papers they were to include in their manuscripts.

Although there are similarities with the themes identified by Dew (2008), the themes are not identical. Health has become a major theme for JFEI, so much so that the theme was divided into two: health affecting family life, and other health (such as insurance). Several of Dew's (2008) identified themes, including caregiving, family resource management, housing, and time use, disappeared as separate themes. Consumer attitudes and behavior evolved into financial behavior. New themes emerged, such as ethnic minorities, retirement, and financial socialization and literacy.

In their future directions' sections, several authors commented on the limitations of cross-sectional data. We have discovered the "what" but we have not identified the "why" or even the "how." The authors suggested more longitudinal research, as well as more qualitative research (interviews, focus groups) in order to delve into change over time, but also to discover the "why" and the "how."

We want to thank all the 38 authors who enthusiastically embraced this review project. Their timelines were severely impacted by the novel coronavirus pandemic. Teaching faculty were required to switch their courses to on-line/ virtual formats mid-semester with little warning or assistance; extension faculty found themselves dealing with a completely new set of demands and lots of questions. Furthermore, many of the authors have children who they were having to home school. So, kudos to these intrepid authors/ scholars who did a magnificent job.

The manuscripts focusing on the 17 themes, authors, and titles, are organized as follows:

\section{Family Composition}

- Family matters: Heather H. Kelley, Ashley B LeBaron, and E. Jeffrey Hill (title: Family Matters: Decade Review from Journal of Family and Economic Issues)

- Marriage and cohabitation: Jeffrey Dew (title: Ten Years of Marriage and Cohabitation Research in the Journal of Family and Economic Issues)

- Retirement: Deanna Sharpe (title: Reinventing Retirement)

- Ethnic minorities: Roudi Roy, Anthony G. James, and Tiffany L. Brown (title: Racial/Ethnic Minority Families)
- Asian family issues: Swarn Chatterjee, Lu Fan, Soomin Ryu, and Jinhee Kim (title: A Decade Review of Asian Studies in the Journal of Family and Economic Issues from 2010 to 2019)

\section{Two Sides of Family Finances}

- Financial/economic stress: Terri Friedline, Zibei Chen, and So'Phelia Morrow (title: Families' Financial Stress \& Well-Being: The Importance of the Economy and Economic Environments)

- Poverty/income: Yoshie Sano and Sheila Mammen (title: Well-Being and Stability among Low-Income Families: A 10-Year Review of Research)

- Financial and economic well-being: Melissa Wilmarth (title: Financial and Economic Well-Being)

\section{Employment}

- Work and family: J. Alberto Molina (title: The WorkFamily Conflict: Evidence from the Recent Decade and Lines of Future Research)

- Family business: George Haynes, Maria Marshall, Yoon Lee, Virginia Zuiker, Cynthia Jasper, Sandra Sydnor, Corinne Valdivia, Diane Masuo, Linda Niehm, and Renee Wiatt (title: Family Business Research: Reviewing the Past, Contemplating the Future)

- Employment and wages: Elena Stancanelli and Elizabeth M. Dolan (title: Women's Employment, Wages, and the Household)

\section{Health}

- Family matters and health: Christopher Tamborini (title: Family and Health over the Past Decade: Review of Selected Studies and Areas of Future Inquiry)

- Health: Anoshua Chaudhuri (title: Health Research in JFEI over a Decade: 2009-2019)

\section{Pathways to Financial Well-Being}

- Financial socialization and literacy: Ashley B. LeBaron and Heather H. Kelley (title: Financial Socialization: A Decade in Review)

- Financial behavior: Kyoung Tae Kim and Jae Min Lee (title: A Decade Review of Financial Behavior Research in Journal of Family Economic Issues) 
- Education: Sophie Li (title: What Impacts Young Generations' School/College Education? A Review on JFEI Publications in the Past Ten Years)

- College financial issues: Suzanne Bartholomae and Jonathan Fox (title: A Decade Review of Research on College Student Financial Behaviors and Well-being)

We hope that what these scholars have presented here will provide insights and ideas for the next ten years.

\section{Reference}

Dew, J. (2008). Themes and trends of Journal of Family and Economic Issues: A review of twenty years (1988-2007). Journal of Family \& Economic Issues, 29, 496-540. https://doi.org/10.1007/s1083 4-008-9118-7.

Publisher's Note Springer Nature remains neutral with regard to jurisdictional claims in published maps and institutional affiliations. 